\title{
O ODGOJNO-OBRAZOVNIM POSTIGNUĆIMA UČENIKA DRUGOG RAZREDA DEVETOGODIŠNJE OSNOVNE ŠKOLE
}

\section{Sažetak}

S obzirom da je školske 2012/2013. godine izašla prva generacija učenika koja je u osnovnu školu upisana po sistemu devetogodišnjeg osnovnog odgoja $i$ obrazovanja, potreba za utvrdivanjem ostvarenih rezultata, ishoda učenja $i$ postavljenih ciljeva još je veća. U vezi s tim, ali is posebnim zadatkom koji se odnosio na praćenje razvojnih karakteristika šestogodišnjaka, kako bi se upotpunila znanja studenata iz predmeta Razvojna psihologija, provedeno je istraživanje o čemu donosimo naša skromna zapažanja.

Aktuelnost praćenja napredovanja, vrednovanja i ocjenjivanja učeničkih postignuća ne prestaje niti će prestati. Potreba za stalnim praćenjem odgojnoobrazovnih postignuća učenika još je izraženija u vrijeme primjene sistema devetogodisnjeg osnovnog odgoja i obrazovanja i opisnog ocjenjivanja u prvoj trijadi osnovne škole. Informacije o ishodima učenja potrebne su ne samo učenicima, nego $i$ roditeljima, starateljima, odgajateljima $i$ svim drugim subjektima koji su na bilo koji način uključeni u odgoj i obrazovanje djece.

$U$ cilju praćenja psihofizičkog razvoja djece $i$ uskladenosti razvoja sa zahtjevima devetogodišnje osnovne škole, studenti Pedagoškog fakulteta Univerziteta u Bihaću proveli su istraživanje o odgojno-obrazovnim postignućima učenika drugog razreda devetogodišnje osnovne škole ${ }^{2}$.

\footnotetext{
${ }^{1}$ Pedagoški fakultet Univerziteta u Bihaću

${ }^{2}$ Istraživanje provedeno uz saglasnost Ministarstva obrazovanja, nauke, kulture i sporta USK-a broj 0601521/12. Zapažanja se odnose na rezultate dobivene u odjeljenjima drugog razreda devetogodišnje osnovne škole na području USK-a. U istraživanju su sudjelovali studenti treće godine Razredne nastave Pedagoškog falulteta Univerziteta u Bihaću čija prezimena i imena navodimo abecednim redom: Bešić Azra, Ćatić Ilvana, Ćehić Hamida, Ćerimović Amela, Dizdarević Timka, Džaferović Alden, Duraković Nerdžana, Hasić Medina, Hrnjić Almina, Koštić Alma, Malovčić Anela, Muhamedagić
} 
Ključne riječi: reforma, strategije ǔcenja, ishodi učenja, postignuća, motivacija, lokus kontrole, opisno ocjenjivanje, socijalna osjetlivost, emocionalna stabilnost, nastavničke i učeničke kompetencije

\section{Uvod}

Početak školovanja, a posebno početak devetogodišnjeg osnovnog odgoja i obrazovanja ima posebne specifičnosti $i$ značaj, tim prije što pretpostavlja dobru pripremljenost djece uzrasta od šest godina, tj. da su spremni i osposobljeni za složene zadatke koje pred njih postavlja ovaj sistem odgoja i obrazovanja.

Devetogodišnje obrazovanje $\mathrm{i}$ odgoj zahtijeva reformu cjelokupnog sistema odgoja i obrazovanja zasnovane na pozitivnim i kvalitetnim iskustvima pedagoške i nastavne prakse u naprednim zemljama Evrope i svijeta. Na području USK-a ovaj proces započeo je 2003. godine i predstavlja reformu sistema odgoja $\mathrm{i}$ obrazovanja, što je zahtijevalo promjene u svim važnim segmentima kao što su promjene u nastavnim planovima i programima, ozbiljne promjene u osmišljavanju i izboru programskih sadržaja svih nastavnih predmeta, $s$ težišstem na programske sadržaje koji su posebno značajni u temeljnom odgoju i obrazovanju, prije svega u pripremi za život, za profesionalno opredjeljenje i izbor budućeg poziva, priprema za nastavak školovanja u srednjoj školi i na fakultetu. Promjene su nastupile i u izboru i korištenju metoda i oblika rada, novih pogleda na vannastavne i vanškolske aktivnosti učenika, promjene u načinu komuniciranja u školi i van nje, promjene u načinu rada kod svih sudionika odgojno-obrazovnog procesa.

Reforma sistema odgoja i obrazovanja u prvi plan stavlja dijete, učenika i njegovu dobrobit, ali i dobrobit porodice i društvene zajednice u cjelini. Dijete, njegovi interesi, sposobnosti, sklonosti, mogućnosti i želje su u središtu pažnje. To pretpostavlja da svakom djetetu koje je dostiglo fizički, psihički, socijalni i emocionalni nivo razvoja, treba obezbijediti jednake mogućnosti odgoja i obrazovanja, osigurati dvosmjernu

Amra, Muharemović Sabima, Mujić Tarik, Mušeljić Denisa, Okanović Ismeta, Pajazetović Amela, Suljkanović Ilvana, Topić Irma. 
komunikaciju, međusobnu saradnju nastavnika i učenika u procesu učenja i kontinuiranog odgoja i obrazovanja, pri čemu ne treba zanemariti značaj i ulogu roditelja. $\mathrm{Na}$ taj način će se ostvariti kompatibilnost našeg sistema odgoja i obrazovanja sa odgojem i obrazovanjem u razvijenim zemljama Evrope i svijeta. Zapaženo je da se u svijetu ove promjene dešavaju mnogo brže (četiri puta brže), ${ }^{3}$ te postoji realna potreba da se neminovno pristupi reformi, da se otklanjaju uočeni nedostaci i da se odgoj i obrazovanje učine efikasnijim i funkcionalnijim. Dakle, neophodno je modernizirati sistem odgoja i obrazovanja od najranijeg školskog perioda i učiniti neophodne korake u smislu modernizacije, demokratizacije i humanizacije sistema odgoja i obrazovanja te ostvarivanja kvalitetne, savremene osnovne škole u našoj zemlji. Svaka reforma, a posebno reforma sistema odgoja i obrazovanja je složen, mukotrpan i dugotrajan proces koji mijenja ljude, a to je i najteže ostvariti. Stoga, u sistemu provođenja reforme neophodno je da sudionici pokažu visok stepen spremnosti za promjene kako bi uspješno, fleksibilno, obazrivo, postupno i sistematski ostvarivali kod učenika, roditelja i drugih subjekata planirane promjene.

Odgajatelji, kao temeljni nosioci reforme, treba da sačuvaju provjerena i dokazana dosadašnja iskustva, znanja i ostvarene rezultate koji su obilježili dosadašnji sistem odgoja i obrazovanja i na temeljima pozitivnih dostignuća, strpljivo, stručno, fleksibilno i dosljedno uvoditi i razvijati novo, moderno, zanimljivo i praktično primjenljivo obrazovanje usklađeno sa interesima, sposobnostima, potrebama i željama učenika. Takav pristup imat će pozitivne posljedice, kako na razvoj kognitivnih i konativnih sposobnosti učenika, tako i na razvoj njihove socijalne i emocionalne strukture ličnosti.

Reforma sistema odgoja i obrazovanja i uvođenje devetogodišnjeg osnovnog odgoja i obrazovanja postala je danas realnost. Ona neminovno nameće potrebu za reformom srednje škole, jer samo tako ima svoj puni smisao i opravdanje. Učenici i roditelji moraju biti sigurni da će nakon

\footnotetext{
${ }^{3}$ www.oszd.edu.ba/dokumenti/Koncepcija_devetogodišnjeg_osnovnog_odgoja_i_ obrazovanja.pdf
} 
završene osnovne škole devetogodišnjeg trajanja, imati mogućnost nastaviti srednjoškolsko obrazovanje i odgoj u skladu sa svojim sposobnostima i mogućnostima, interesima, sklonostima i željama. $\mathrm{Ne}$ bi se smjelo nikako dogoditi da se učenici i njihovi roditelji, nakon završene osnovne škole, razočaraju i dožive neuspjeh u ostvarivanju planiranih želja, samo zbog toga što su pojedini segmenti cjelokupne reforme zatajili i nisu u punoj mjeri ostvarili postavljene ciljeve i zadatke. U protivnom, reforma osnovne škole postaje sama sebi svrha i gubi osnovnu i motivirajuću ulogu za naredno školovanje.

\section{Teorijska razmatranja}

Početak školovanja zasigurno predstavlja značajnu prekretnicu u životu djece i u njihovom psihofizičkom razvoju. Zato nije nimalo beznačajno kako će se dijete pripremiti za novi način života, kako će sa obavezama i odgovornostima zamijeniti igre i bezbrižnost. Psihološka istraživanja ukazuju na to da djeca ovog uzrasta mogu relativno samostalno izvršavati mnoge zadatke koji redovno prate dijete na početku školovanja. Također, psihološka istraživanja potvrđuju da su šestogodišnjaci fizički, psihički, socijalno i emocionalno dostigli takav nivo razvoja koji im omogućava uspješno savladavanje svih prepreka na koje će nailaziti.

Reforma sistema odgoja i obrazovanja zasnovana je na globalnom cilju obrazovanje za život. Ovako postavljen globalni cilj pretpostavlja kontinuirano stjecanje znanja, razvoj sposobnosti i vještina, formiranje pozitivnih stavova i navika, usvajanje vrijednosti, razvoj punih potencijala svakog djeteta u granicama njegovih mogućnosti.

Civilizacijski i znanstveni smisao ovako postavljenog cilja odgoja i obrazovanja temelji se na obrazovanju $z a$ biti ili obrazovanju za život; obrazovanju za znati, a to znači izbor vrijednih sadržaja iz postojećeg ljudskog iskustva obuhvaćeno kognitivnim, konativnim i emocionalnim razvojem pojedinca; obrazovanju za djelovati, a to znači praktično djelovanje i aktivan odnos prema svim pitanjima, problemima, izazovima iz neposredne životne sredine; posebno značajno je obrazovanje $z a$ zajednički život zasnovan na interkulturalizmu, multikulturalizmu kao stvarnost pluraliteta kulture, vjere, jezika, običaja, tradicije, načina 
odijevanja i prehrane. Dakle, zajednički i odgovoran suživot. Uz globalni cilj, reformom su predviđeni i specifični ciljevi odgoja i obrazovanja koji se odnose na učenike, nastavnike, odgajatelje, škole, roditelje i društvo u cjelini. $^{4}$

Vrijeme u kojem živimo zahtijeva promjene i dopune teorije i prakse sa novim idejama, novim pristupima u radu koji će omogućiti pripremu mladih za život, za promjene koje se događaju na planu svjetske globalizacije. Promjene našeg obrazovnog sistema uključuju, pored ostalog, usklađivanje odgoja i obrazovanja i prilagođavanje cjelovitom odgoju i obrazovanju kakvo je u modernom, demokratskom i pluralnom društvu, te ostvarivanje takvih znanja i kompetencija koje će našem budućem čovjeku osigurati jednake šanse na globalnom i međunarodnom tržištu. Nove reformske promjene obogaćene novim školskim kurikulumima kroz sve nastavne predmete, pojedinačno i integralno, nove kompetencije nastavnika, bogata i kompetentna znanja učenika, osavremenjen savjetodavni rad pedagoške službe, solidna materijalna podloga i uvjeti rada škola - svakako će značiti veliku promjenu sistema odgoja i obrazovanja praćenog novim i modernijim tehnologijama. I skromna istraživanja efekata i ishoda odgoja i obrazovanja $\mathrm{u}$ toku provođenja reforme, jasno ukazuju na slabu razvijenost standarda odgoja i obrazovanja, slabu materijalnu opremljenost naših škola, preskroman materijalni položaj prosvjetnih radnika, nedovoljnu kontrolu kvaliteta ishoda učenja, nefunkcionalan položaj pedagoške službe, što sve u značajnoj mjeri otežava proces provođenja reforme i ostvarivanje globalnog i specifičnih ciljeva zacrtanih Koncepcijom devetogodišnjeg odgoja i obrazovanja.

Imajući u vidu, te uvažavajući i uzimajući u obzir specifičnosti višenacionalnih sredina u Bosni i Hercegovini, neophodno je da programi zajedničke jezgre uključe sve nastavne planove i programe, sa što je moguće širim zajedničkim osnovama u svim nastavnim

\footnotetext{
${ }^{4}$. www.oszd.edu.ba/dokumenti/Koncepcija_devetogodišnjeg_osnovnog_odgoja_i obrazovanja.pdf
} 
predmetima i tako osigurati koheziju sistema odgoja i obrazovanja u našoj zemlji.

Lokalna komponenta daje mogućnost školama da, u skladu sa zavičajnim potrebama, razvijaju, dopunjuju i obogaćuju vlastite programe sa lokalnim sadržajima i područjima učenja. Ovdje se iskazuje sposobnost, znanje i stručnost svakog nastavnika da realno procjenjuje, uvažava $\mathrm{i}$ dopunjuje programske sadržaje predmeta kojeg realizira sa specifičnim sadržajima lokalne sredine u kojoj je škola.

Mjerenje postignuća, ishoda nastave i učenja treba da bude zasnovano na standardima postignuća koja se utvrđuju tokom i na kraju školske godine, kao i nakon završenog osnovnog odgoja i obrazovanja svake generacije učenika. Standardi moraju uključiti znanja, sposobnosti, razumijevanja, vrijednosti i stavove čime se osigurava kompleksnost i cjelovitost za svakog učenika. To će biti moguće ako se u nastavnom procesu osigura i primjenjuje međupredmetna povezanost, čime bi se programski sadržaji, osim kroz nastavne predmete, realizirali i kroz veće cjeline, teme koje se odnose na više nastavnih predmeta. To svakako zahtijeva da se u procesu planiranja rada i realizacije programskih sadržaja primjenjuje i tematsko planiranje. Upravo je tu šansa da se ostvari međupredmetna korelacija, stvaralački pristup planiranju i stručna i bogata saradnja među nastavnicima. $S$ obzirom da su škole i nastavnici koji rade u njima slobodni i kompetentni da odlučuju, biraju, planiraju i realiziraju integrativne teme, dužni su da s puno volje, znanja i stručnosti pristupaju realizaciji ovog značajnog zadatka. Brojni su primjeri iz nastavne prakse koji ovo potvrđuju. U razrednoj nastavi ova potreba posebno je izražena. Tematsko planiranje realizacije programskih sadržaja bosanskoga jezika i moje okoline, ali i tematsko povezivanje sa muzičkom kulturom. Matematika, tjelesni i zdravstveni odgoj i likovna kultura također pružaju velike mogućnosti za realizaciju integrativnih tema. I u predmetnoj nastavi mogućnosti realizacije programskih sadržaja kroz planiranje integrativnih tema su veoma izražene. Tematsko planiranje sadržaja matematike i fizike, fizike i hemije, historije i geografije, bosanskoga jezika i književnosti, historije i stranog jezika te široke mogućnosti integrativnog planiranja programskih sadržaja odgojnih 
područja i ostalih nastavnih predmeta. Mora se priznati da je ovakav pristup planiranju složen, odgovoran i težak zadatak koji zahtijeva visok nivo saradnje i stručnosti. U samom početku zahtijeva puno angažiranje, ali u konačnici, za rezultat ima bolji, zanimljiviji, sadržajniji i bogatiji rad i sigurno bolje rezultate učenja. U ostvarivanju ovako složenog i značajnog zadatka značajnu pomoć mogu pružiti stručni saradnici u školi. Tu prije svega mislimo na školske pedagoge, školske psihologe, specijalne pedagoge, socijalne radnike, ljekare i dr. Njihova podrška i pomoć sigurno će značajno doprinijeti cjelokupnom nivou nastavnog procesa kao i konačnim ishodima učenja učenika. Ne treba zanemariti ni ulogu roditelja, jer njihova partnerska pozicija jača i učvršćuje cjelokupni rad. Kroz vijeća roditelja i školske odbore, roditelji imaju značajan udio u cjelokupnom životu i radu škole. Roditeljske kompetencije u praćenju razvoja i napredovanja djeteta moraju biti rezultat edukacije roditelja. Škole trebaju iskoristiti potencijale $s$ kojima raspolažu roditelji jer se radi o vrlo heterogenoj strukturi s obzirom na znanja, sposobnosti, zanimanja i mogu s različitih aspekata doprinijeti uspješnoj realizaciji ciljeva i zadataka odgoja i obrazovanja određenog uzrasta učenika.

$\mathrm{Ne}$ treba zanemariti dobrobit za učenike koja i jeste svrha. Učenici ovakvu nastavu doživljavaju zanimljivijom, korisnijom i što je posebno značajno, njihova pozicija subjekta u nastavnom procesu dolazi do punog izražaja, a ishodi učenja bolji. Sa psihološke strane gledišta, učenici se osjećaju superiornijim, angažiranijim. Osjećaju ravnopravnost, uvažavanje i saradnju. U takvim odnosima njihova ličnost se pravilno razvija i oblikuje uz inkorporiranje niza pozitivnih karakternih crta ličnosti, pa su emocionalno stabilni, socijalno osjetljivi, aktivni, uporni, staloženi, empatični. ${ }^{5}$

Koncepcija devetogodišnje škole temelji se na slijedećim principima:

\footnotetext{
${ }^{5}$ Ramić, O, Utjecaj karaktera učenika na školski uspjeh i ponašanje,:Pedagoški fakultet, Bihać, 2011, str. 79-90. Ovom knjigom autor želi da svima onima koji su direktno ili indirektno vezani za odgojno-obrazovni rad s djecom i mladima omogući korištenje rezultata istraživanja jednog značajnog područja iz oblasti psihologije, a koje se odnosi na ličnost, njen razvoj, s posebnim naglaskom na karakterne crte kao pretpostavke uspješnog učenja i ponašanja.
} 
princip individualizacije, princip racionalizacije, princip aktuelnosti, princip sistematičnosti, princip znanstvenosti, princip postupnosti te princip povezivanja teorije i prakse.

I dosadašnja škola koristila je navedene principe, ali se u novoj školi traži veća dosljednost u njihovom provođenju.

I organizacione forme nastavnog rada su, uglavnom, preuzete iz dosadašnjeg sistema odgoja i obrazovanja. To su, prije svega, etape ili faze nastavnog rada, sociološki oblici rada, nastavne metode, nastavna sredstva i pomagala, tehnika i tehnologija nastavnog rada koja je sada puno modernija, aktuelnija i privlačnija.

Prema koncepciji devetogodišnje škole u organizaciji nastavnog procesa, prednost treba dati individualiziranim oblicima rada koji se mogu realizirati kroz programiranu ili poluprogramiranu nastavu, kroz algoritmizaciju učenja, kroz problemsku nastavu, nastavu putem otkrića, doživljajnu nastavu itd. Od socioloških oblika rada treba preferirati tandemski oblik rada, rad u malim ili u većim grupama, dok frontalni oblik rada treba da bude zastupljen u neznatnoj mjeri. U primjeni i korištenju nastavnih metoda rada, treba uvažavati prednosti koje pruža polimetodizam, uz maksimalno korištenje metoda u kojima učenici aktivno sudjeluju u nastavnoj spoznaji. Dakle, treba primjenjivati interakciju različitih nastavnih metoda i postupaka i ostvariti komunikaciju zasnovanu na međusobnom uvažavanju na relaciji nastavnik - učenik, učenik - učenik, učenik - nastavnik itd. Napuštaju se strategije učenja i poučavanja svojstvene frontalnom radu i jednosmjernoj komunikaciji u razredu. Naglašena prednost se daje strategijama problemskog učenja, učenja putem otkrića, integrativnom učenju, akcelerativnom učenju, učenju softverskih paketa i istraživačkom učenju. Posebno značajan zahtjev moderne škole je da se strategije rada nastavnika temelje na demokratskim načelima i povoljnoj socioemocionalnoj klimi u razredu. Napuštaju se strategije predavanja, davanja gotovih znanja, a uvode se strategije koordiniranja, vođenja, usmjeravanja, poticanja, kontinuiranog motiviranja uz stalno davanje povratnih informacija o napredovanju učenika i ishodima njegova učenja. To zahtijeva istaknuto polazište nove devetogodišnje škole da učenik 
bude u centru zbivanja, da je aktivni sudionik nastavnog procesa te da se maksimalno uvažavaju sposobnosti, interesi, mogućnosti, znanja i želje svakog djeteta. ${ }^{6}$

\section{Metodologija istraživanja}

\section{a) Predmet istraživanja}

Predmet istraživanja su efekti osnovnog devetogodišnjeg odgoja i obrazovanja i praćenje psihofizičkog i socioemocionalnog razvoja učenika drugog razreda devetogodišnje osnovne škole. U cilju upotpunjavanja znanja studenata iz predmeta Razvojna psihologija i njihovog osposobljavanja za mala operativna istraživanja koja će provoditi u budućem nastavnom radu, organizirano je terensko istraživanje koje je uključilo 19 studenata sa Odsjeka za razrednu nastavu na Pedagoškom fakultetu Univerziteta u Bihaću.

\section{b) Cilj i zadaci istraživanja}

Cilj istraživanja bio je višestruk. Prvo što je planirano ostvariti istraživanjem bilo je da se studenti provjere u kojoj mjeri su osposobljeni za praćenje i utvrđivanje razvojnih karakteristika šestogodišnjaka, $s$ obzirom na činjenicu da su upisani u osnovnu školu po sistemu devetogodišnjeg osnovnog odgoja i obrazovanja. Pored toga, zadatak nam je bio da studente osposobljavamo za istraživački rad i da se neposredno uvjere u prednosti i vrijednosti provođenja malih operativnih istraživanja pitanja i problema koji su redovni pratioci nastavnog procesa. Uz sve to, željeli smo doznati efekte ishoda učenja djece koja su pošla u školu sa navršenih 5,5 do 6 godina života.

\section{c) Hipoteze istraživanja}

Osnovna hipoteza:

\footnotetext{
${ }^{6}$ Više o ovome u knjizi Vizek-Vidović,V., Vlahović-Štetić, V., Rijavec, M., Miljković, D, Psihologija obrazovanja,. IEP Vern, Zagreb, 2003, str. 321-404.
} 
Polaskom šestogodišnje djece u osnovnu školu u sistemu devetogodišnjeg osnovnog odgoja i obrazovanja, ne narušava se skladnost njihovog fizičkog i psihičkog (kognitivnog, socijalnog, emocionalnog) razvoja.

Podhipoteze:

a) Učenici drugog razreda devetogodišnje osnovne škole su sposobni da uspješno savladaju zahtjeve čitanja i pisanja kao i zahtjeve gramatike, pravopisa i kulture izražavanja koji su propisani NPP-om;

b) Tvrdimo da šestogodišnja djeca, bez posebnih poteškoća, savladavaju osnovne računske operacije sabiranja i oduzimanja u krugu broja 20 i da uspješno ovladavaju matematičkim pojmovima na nivou II. razreda;

c) Interes učenika II. razreda za programske sadržaje nastavnog predmeta Moja okolina nije narušen zbog njihovog ranijeg polaska u osnovnu školu;

d) Odgojna područja: Muzička kultura, Likovna kultura, Tjelesni i zdravstveni odgoj sa svojim programskim zahtjevima podstiču razvoj psihomotornih sposobnosti i daju veliki doprinos u cjelovitom razvoju djece bez obzira na vrijeme polaska u školu;

e) Socioemocionalna stabilnost i uravnoteženost učenika drugog razreda devetogodišnje osnovne škole uspješno se ostvaruje u povoljnoj socioemocionalnoj klimi u razredu;

f) Devetogodišnje osnovno obrazovanje i odgoj na postepen, prilagodljiv i primjeren način priprema djecu za život, orijentiranost na znanje, organizirano i kontinuirano djelovanje te, što je posebno značajno, za zajednički život i odgovoran suživot. Time se na najbolji način podstiče interkulturalizam, multikulturalnost kao stvarnost pluraliteta kultura, vjera, jezika, tradicije i svih drugih vrijednosti značajnih za razvoj čovjeka.

\section{Metode istraživanja}

Dominantna metoda $\mathrm{u}$ istraživanju bila je metoda sistematskog posmatranja, za koju svrhu su pripremljeni odgovarajući protokoli. Korištena je i metoda proučavanja pedagoške dokumentacije, metoda razgovora, a od istraživačkih tehnika - tehnika anketiranja. 


\section{Uzorak istraživanja}

Uzorak čine učenici II. razreda, njih 382 raspoređenih u 21 odjeljenje u osnovnim školama na području USK-a. U cilju potpunijeg uvida u efekte devetogodišnjeg odgoja i obrazovanja, istraživanje je provedeno u odjeljenjima gradskih, prigradskih i seoskih škola. Iako broj škola i odjeljenja ne zadovoljava zahtjeve reprezentativnosti, a broj učenika obuhvaćenih istraživanjem donekle $\mathrm{i}$ zadovoljava, smatramo da su percepcije studenata i njihova eksplikacija od dragocjene vrijednosti i da mogu doprinijeti unapredivanju nastavne prakse.

\section{Rezultati istraživanja $i$ interpretacija rezultata}

\section{Neka zapažanja o efektima devetogodišnjeg osnovnog odgoja i obrazovanja}

Mišljenja nastavnika o efikasnosti, prednostima i nedostacima devetogodišnje osnovne škole u odnosu na dosadašnju osmogodišnju školu su veoma različita i kreću se od nepovoljnih, prema kojima je devetogodišnje obrazovanje i odgoj promašaj i da se treba vratiti na stari sistem odgoja i obrazovanja, pa do onih koji ističu izrazite prednosti u pogledu cjelokupnog sistema. Na ovoj skali ima niz mišljenja i tvrdnji koja se protežu duž skale, lijevo i desno od zamišljene središnje vrijednosti, s obzirom na nastavni predmet ili odgojno područje.

U vezi s tim, neophodno je konstatirati da su sva opažanja do kojih su studenti došli zasnovana na opservacijama u odjeljenjima drugog razreda osnovne škole, pa se i ne može donositi konačan sud o efikasnosti devetogodišnje škole. $S$ obzirom da je prva generacija devetogodišnjaka krenula školske 2013/2014. godine u srednju školu, bilo bi uputno i jako korisno provesti temeljitije istraživanje tokom prvog polugodišta prvog razreda srednje škole. Smatramo da bi se sa visokom sigurnošću moglo doći do meritornih kvalifikacija koje se odnose na ovo pitanje, ali to nije predmet našeg rada. Naša opažanja su zasnovana na navedenim osnovama bez pretenzija da izvodimo konačne zaključke, jer to i nije moguće. Osim toga, radi se o opažanjima studenata III godine studija razredne nastave, čija su istraživačka iskustva skromna i kojima tek 
predstoji stjecanje i razvijanje istraživačkih sposobnosti. Ipak, smatramo da konstatacije koje ćemo izložiti mogu biti od koristi u smislu poticanja na ove i slične aktivnosti, ali i korisne i aplikativne na praksu. Zagrizli su nezrelu jabuku čiji okus ih podsjeća da joj se ponovo vrate.

Evo nekih mišljenja nastavnika:

Volim ovo što radim $i$ radim to s puno volje i elana. Najljepši mi je osjećaj kada nakon mukotrpnog poučavanja vidim rezultate svoga rada. Tada sam jako sretna", ističe učiteljica koja ima 16 godina radnog iskustva u nastavi.

Nastavnici ističu da je program devetogodišnje osnovne škole prenatrpan, da je malo nastavnih sati za ponavljanje i uvježbavanje, da udžbenici samo djelomično zadovoljavaju zahtjeve NPP-a, da su tekstovi preopširni i slabo poučni za uzrast prve trijade.

Što se tiče razvojnih karakteristika učenika ovog uzrasta, što je i bio jedan od zadataka našeg opažanja i istraživanja, odgajatelji ističu da su djeca ovog uzrasta na različitom stepenu razvoja koji se manifestira od jako naglašene potrebe za općim i najjednostavnijim uputama o načinu prepisivanja u sveske, prelaska $u$ novi red, zbijenog pisanja da se ne bi riječ rastavljala, davanja nepotpunih odgovora, pa do potpuno ispravnih, cjelovitih i samostalno pripremljenih rješenja. ${ }^{7}$

Ovaj uzrast učenika traži od nastavnika veliko strpljenje, staloženost, visok nivo empatije, jer nastavnici najčešće moraju čekati dugo na odgovor učenika. Učenici su nestrpljivi i skakuću u mjestu dok čekaju da im se omogući da odgovore na pitanja. Dakle, aktivnost učenika kreće se od onih koji su jako aktivni i veoma komunikativni, do onih koji su stidljivi, zatvoreni, nepristupačni, povučeni, što svakako zahtijeva

${ }^{7}$ Mišljenja nastavnika iznesena u Anketi provedenoj u sklopu istraživanja. Anketa se između ostalog odnosila na :

- mišljenja nastavnika o zadovoljstvu izborom poziva,

- o učenicima i njihovom odnosu prema obavezama,

- zapažanja o nastavnom planovima i programina i udžbenicima,

- saradnju s Pedagoškim zavodom i Ministarstvom obrazovanja, nauke, kulture i sporta USK-a. 
poseban rad, tretman i strpljenje od strane odgajatelja. Značajnu pomoć u radu mogu dati roditelji koji treba da budu aktivni sudionici odgojnog djelovanja, ali i ta pomoć ima svoj kontinuum - od veoma zainteresiranih i aktivnih, do potpuno nezainteresiranih i nebrižnih. Iako je atmosfera u učionici prožeta sa povoljnim socioemocionalnim obilježjima, ako su djeca aktivna i opuštena, opažanja studenata se svode na konstataciju da su djeca ovog uzrasta nezrela za bremenite obaveze. Opažanja o zrelosti djece idu u prilog djevojčicama koje su se pokazale aktivnijim, odgovornijim u izvršavanju zadataka, urednijim i tačnijim, pa bi se moglo zaključiti da se djevojčice ovog uzrasta psihofizički brže razvijaju u odnosu na dječake.

Jedna od vrlo bitnih pozitivnih karakteristika devetogodišnje osnovne škole, a koju su nastavnici, praktičari isticali je i zakonski propis prema kojem dijete svakako treba da završi razred. Dakle, nema gubljenja godine i sve se mora činiti kako bi djeca, u skladu sa svojim sposobnostima i mogućnostima imala osiguranu nastavu i uspješno završila razred. Ovo je posebno značajno za djecu s teškoćama u razvoju za koje je neophodno pripremati prilagođene nastavne planove i programe, koji, pored kognitivnih sposobnosti i konativnih osobina ličnosti, moraju voditi računa i o njihovom emocionalnom, socijalnom, govornom i cjelokupnom psihofizičkom razvoju.

Ne smije se zanemariti činjenica da je kod učenika prve trijade pažnja još uvijek kratkotrajna, labilna, jako podložna promjenama. O tom valja voditi računa u organizaciji i izvođenju nastavnog sata. Pamćenje kod ove djece zahtijeva česta ponavljanja radnji, pokreta, sadržaja. Stoga, naizmjenično smjenjivanje obrade programskih sadržaja i aktivnosti različitog nivoa i zahtjeva mogu biti od velike koristi i za djecu i za odgajatelje.

Izbor škola i odjeljenja sasvim je slučajan. Zasnovan je na željama i opredjeljenju studenata koji su uključeni u provođenje istraživačkog projekta i slobodnom izboru u skladu s mjestom stalnog boravka i poznavanjem škole i uvjeta rada. I pored toga, bili smo primorani da iz dalje obrade rezultata isključimo tri škole (odjeljenja i učenike), jer su podaci bili nepotpuni i neprecizni. Iako nam nije bio cilj postići 
odgovarajuću reprezentativnost uzorka škola, odjeljenja i učenika, ona je $\mathrm{u}$ određenoj mjeri ostvarena, jer su u istraživanje uključeni učenici iz gradskih, prigradskih i seoskih sredina, gotovo ravnopravno. Nemamo aspiracije da na osnovu naših skromnih rezultata vršimo određene generalizacije o pitanjima i problemima koji opterećuju devetogodišnji odgojno-obrazovni sistem. Za takvo nešto bilo bi potrebno provesti daleko šira i sveobuhvatnija istraživanja, a to prevazilazi naše materijalne mogućnosti. Dimenzija reprezentativnosti uzorka opterećena je i brojem učenika u odjeljenjima, koji je u seoskim i prigradskim sredinama manji. Tako smo imali odjeljenja sa 7, 9 ili 13 učenika, dok su odjeljenja u gradskim sredinama sa znatno većim brojem učenika. I pored ovih objektivnih manjkavosti, smatramo da su rezultati i zapažanja do koji su studenti došli, značajni i da mogu biti korisni za unapređivanje nastavne prakse. Posebno se to odnosi na zapažanja o fizičkom i psihičkom razvoju djece ovog uzrasta, kao i o njihovoj socijalnoj osjetljivosti i emocionalnoj stabilnosti. Neposredno doživljavanje života i rada škole, odjeljenja i učenika ima višestruku korist za pripremu i osposobljavanje studenata za odabrani poziv.

\section{Šta su pokazali ostvareni rezultati?}

S obzirom da je osposobljenost učenika za čitanje i pisanje osnovni preduvjet za uspješno učenje, pokušali smo utvrditi nivo ostvarenih rezultata u ovoj oblasti. Odlučili smo se za praćenje nekoliko osnovnih elemenata bez kojih nema uspješnog učenja. U oblasti čitanja to su:

- čitanje tečno s razumijevanjem,

- tečno čitanje;

- ščitavanje, zna šta je pročitao,

- sricanje uz teže razumijevanje,

- zna štampana slova (slabo čitanje) i

- nije osposobljen za čitanje.

Osposobljenost za pisanje pratili smo kroz slijedeće elemente: 
- uredno i tačno prepisuje i zapisuje,

- brzina pisanja, zapisivanja, primjerena,

- uspješno piše rečenice po diktatu,

- nepotpuno prepisivanje (ispuštanje slova),

- nečitko i nepovezano pisanje i

- nije savladao pisanje.

$\mathrm{Uz}$ navedene elemente pratili smo i sposobnost učenika za upotrebu i pisanje slova $\check{c}$ i $c$, osjećaj za rečenicu te upotrebu velikog slova na nivou zahtjeva NPP-a. 
T 1: Osposobljenost učenika za čitanje ${ }^{8}$

\begin{tabular}{|c|c|c|c|c|c|c|}
\hline $\begin{array}{l}\frac{0}{\overrightarrow{0}} \\
\frac{\sqrt[0]{0}}{\sigma} \\
0\end{array}$ & 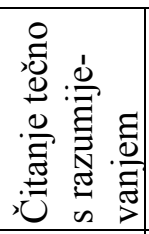 & 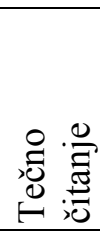 & 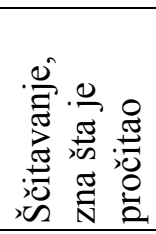 & 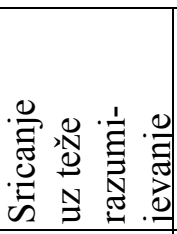 & 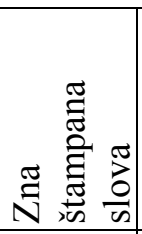 & 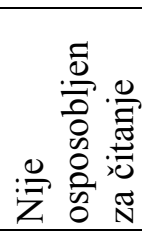 \\
\hline$X$ & 7 & 4 & 5 & 2 & 1 & 1 \\
\hline $\mathrm{X} 1$ & 7 & 1 & 0 & 2 & 2 & 1 \\
\hline $\mathrm{X} 2$ & 8 & 6 & 3 & 2 & 1 & 1 \\
\hline $\mathrm{X} 3$ & 14 & 3 & 3 & 2 & 0 & 0 \\
\hline $\mathrm{X} 4$ & 6 & 2 & 3 & 1 & 1 & 0 \\
\hline $\mathrm{X} 5$ & 11 & 7 & 4 & 3 & 1 & 1 \\
\hline $\mathrm{X} 5-\mathrm{a}$ & 9 & 5 & 2 & 1 & 1 & 0 \\
\hline $\mathrm{X} 6$ & 16 & 4 & 3 & 2 & 0 & 0 \\
\hline $\mathrm{X} 7$ & 4 & 2 & 0 & 0 & 0 & 0 \\
\hline $\mathrm{X} 8$ & 8 & 2 & 2 & 0 & 0 & 0 \\
\hline X9 & 10 & 7 & 1 & 1 & 0 & 0 \\
\hline $\mathrm{X} 10$ & 7 & 1 & 1 & 0 & 0 & 0 \\
\hline $\mathrm{X} 11$ & 10 & 4 & 6 & 0 & 0 & 0 \\
\hline $\mathrm{X} 12$ & 8 & 5 & 3 & 2 & 1 & 0 \\
\hline $\mathrm{X} 13$ & 13 & 1 & 1 & 0 & 0 & 1 \\
\hline $\mathrm{X} 14$ & 7 & 4 & 1 & 0 & 0 & 1 \\
\hline $\mathrm{X} 15$ & 15 & 3 & 2 & 1 & 0 & 0 \\
\hline $\mathrm{X} 16$ & 11 & 3 & 2 & 1 & 0 & 1 \\
\hline $\mathrm{X} 17$ & 10 & 7 & 3 & 2 & 1 & 2 \\
\hline $\mathrm{X} 18$ & 14 & 3 & 2 & 0 & 0 & 0 \\
\hline X19 & 9 & 3 & 7 & 1 & 1 & 1 \\
\hline Svega & 204 & 77 & 56 & 24 & 10 & 11 \\
\hline
\end{tabular}

U T 1 navedeni su podaci koji se odnose na osposobljenost učenika za čitanje koja predstavlja polaznu osnovu za sve ostale aktivnosti djece i preduvjet uspješnog praćenja nastave. Od 382 učenika, 332 ili 88\% ih je u kategoriji uspješnih čitača, što je izvanredan pokazatelj. U periodu istraživanja (april, maj) samo 11 učenika ili 2,8 \% bilo je na nivou savladavanja slova što, s obzirom na period, ne predstavlja zabrinjavajući podatak. Elementi kulture izražavanja, književnih elemenata, analiza likova u zadanim tekstovima te izraženost volje za čitanje književnih djela su u skladu s osposobljenošću učenika za čitanje.

${ }^{8}$ Odjeljenja su obilježena oznakom X - X19 kako bi se ispoštovala obećana anonimnost odjeljenja i nastavnika- 


\section{T 2: Osposobljenost učenika za pisanje}

\begin{tabular}{|c|c|c|c|c|c|c|}
\hline 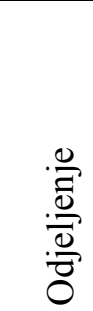 & 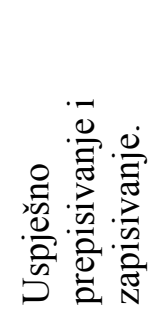 & 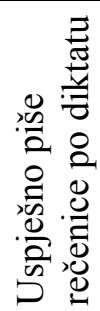 & 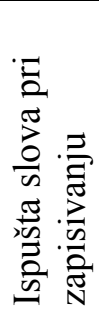 & 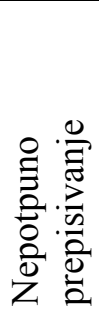 & 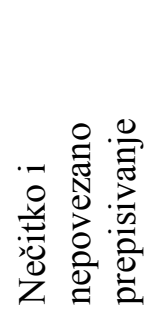 & 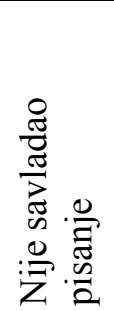 \\
\hline$X$ & 6 & 5 & 2 & 3 & 2 & 2 \\
\hline X1 & 4 & 4 & 0 & 4 & 0 & 1 \\
\hline $\mathrm{X} 2$ & 13 & 5 & 2 & 1 & 0 & 0 \\
\hline X3 & 16 & 4 & 1 & 1 & 0 & 0 \\
\hline $\mathrm{X} 4$ & 10 & 3 & 0 & 0 & 0 & 0 \\
\hline$\times 5$ & 12 & 10 & 3 & 1 & 1 & 0 \\
\hline X5-a & 7 & 6 & 2 & 1 & 1 & 1 \\
\hline X6 & 15 & 4 & 2 & 2 & 1 & 1 \\
\hline $\mathrm{X} 7$ & 4 & 2 & 0 & 0 & 0 & 0 \\
\hline X8 & 7 & 2 & 2 & 1 & 0 & 0 \\
\hline X9 & 10 & 7 & 1 & 1 & 0 & 0 \\
\hline $\mathrm{X} 10$ & 6 & 2 & 1 & 0 & 0 & 0 \\
\hline $\mathrm{X} 11$ & 10 & 7 & 2 & 1 & 0 & 0 \\
\hline $\mathrm{X} 12$ & 7 & 3 & 3 & 2 & 2 & 2 \\
\hline $\mathrm{X} 13$ & 11 & 3 & 0 & 1 & 1 & 0 \\
\hline X14 & 6 & 4 & 2 & 0 & 0 & 1 \\
\hline $\mathrm{X} 15$ & 14 & 5 & 1 & 0 & 1 & 0 \\
\hline X16 & 11 & 5 & 1 & 0 & 0 & 0 \\
\hline X17 & 12 & 8 & 3 & 1 & 1 & 0 \\
\hline X18 & 8 & 5 & 2 & 1 & 2 & 1 \\
\hline X19 & 8 & 8 & 3 & 1 & 1 & 1 \\
\hline SV. & 197 & 102 & 34 & 24 & 14 & 11 \\
\hline
\end{tabular}

Osposobljenost učenika za pisanje koje je praćeno preko osposobljenosti za pisanje te uspješnog zapisivanja rečenica po diktatu je vrlo dobro, jer 299 učenika ili 78 \% je uspješno u ovim zahtjevima. Pojavu ispuštanja slova pri zapisivanju i prepisivanju, kao i pojavu nepotpunog i nečitkog prepisivanja i zapisivanja, smatramo efemernom i da će do kraja nastave biti prevaziđene. I u osposobljenosti za pisanje, kao i u osposobljenosti za čitanje je 11 učenika ili 2,8 \%. Vjerujemo da će se i ovo stanje promijeniti u pozitivnom smislu nakon poduzetih odgovarajućih mjera, 
primjene adekvatnih metoda rada, prilagođavanja nastave i uvažavanja individualnih razlika među djecom koje su objektivne.

Svakako da treba posvetiti odgovarajuću brigu razvijanju psihomotornih sposobnosti, psihomotorici šake i razvoju perceptivnih i senzornih sposobnosti, a sve u funkciji osposobljavanja za uspješno čitanje i pisanje kao preduvjeta za uspješno bavljenje ostalim aktivnostima.

Praćenje matematičkih sposobnosti vršeno je uz provjeravanje osposobljenosti učenika za osnovne računske operacije sabiranja i oduzimanja u krugu broja 20, jer su ova znanja temeljne osnove za ostale složenije matematičke operacije. $U$ vezi s tim, opredijelili smo se za praćenje i obradu slijedećih elemenata sabiranja i oduzimanja:

- brzo i lahko vrši operacije sabiranja u krugu broja 20,

- brzo i lahko vrši operacije oduzimanja u krugu broja 20,

- sabiranje i oduzimanje sa prijelazom vrlo uspješno,

- sabiranje i oduzimanje sa prijelazom uspješno uz napor,

- koristi didaktička pomagala sa sabiranje i oduzimanje,

- uspješno rješava praktične zadatke,

- praktične zadatke rješava uz pomoć didaktičkih sredstava,

- ne može da rješava praktične zadatke,

- jako uredno piše brojeve u odgovarajuće prostore,

- ispravno piše brojeve, ali slabo osjeća prostor,

- brojeve piše nečitko i ne koristi pravilno prostor.

Zbog jednostavnije obrade i tabelarnog prikazivanja rezultata odlučili smo se navedene elemente svesti na šest općenitijih elemenata, a koji u suštini odražavaju i ostale navedene elemente. To su:

- izvanredno izvodi operacije sabiranja i oduzimanja,

- vrlo dobro obavlja operacije sabiranja i oduzimanja,

- dobro (prosječno) obavlja operacije sabiranja i oduzimanja, 
- sabira i oduzima uz veliki napor i jednostavne slučajeve,

- ispodprosječno obavlja operacije sabiranja i oduzimanja i

- ne može da vrši uspješno sabiranje i oduzimanje brojeva u krugu broja 20 .

\section{T 3: Matematičke sposobnosti}

\begin{tabular}{|c|c|c|c|c|c|c|}
\hline $\begin{array}{l}\frac{0}{\overrightarrow{0}} \\
\frac{\sqrt[0]{0}}{0} \\
0\end{array}$ & 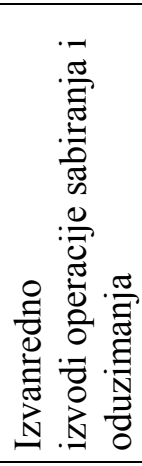 & 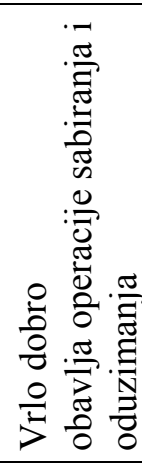 & 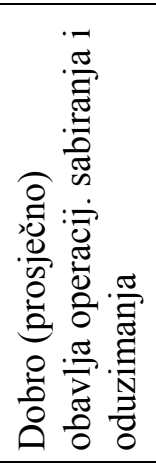 & 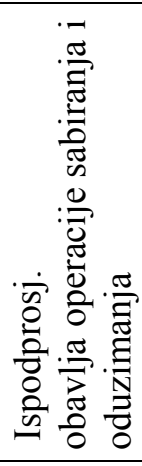 & 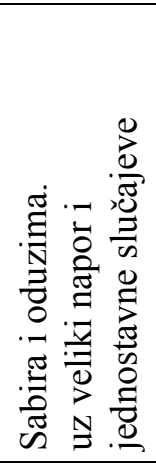 & 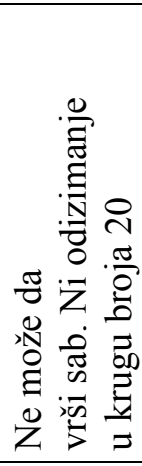 \\
\hline$X$ & 8 & 7 & 2 & 2 & 1 & 0 \\
\hline X1 & 4 & 4 & 3 & 1 & 0 & 1 \\
\hline $\mathrm{X} 2$ & 7 & 7 & 5 & 1 & 1 & 0 \\
\hline X3 & 10 & 6 & 2 & 2 & 1 & 1 \\
\hline $\mathrm{X} 4$ & 3 & 6 & 2 & 1 & 1 & 0 \\
\hline$\times 5$ & 9 & 5 & 5 & 3 & 3 & 2 \\
\hline X5a & 8 & 6 & 2 & 1 & 1 & 0 \\
\hline X6 & 11 & 7 & 5 & 1 & 0 & 1 \\
\hline X7 & 1 & 4 & 1 & 0 & 0 & 0 \\
\hline $\mathrm{X} 8$ & 6 & 3 & 1 & 1 & 0 & 0 \\
\hline X9 & 12 & 7 & 3 & 1 & 0 & 0 \\
\hline $\mathrm{X} 10$ & 2 & 5 & 2 & 0 & 0 & 0 \\
\hline X11 & 8 & 7 & 3 & 1 & 1 & 0 \\
\hline $\mathrm{X} 12$ & 9 & 7 & 3 & 0 & 0 & 0 \\
\hline X13 & 10 & 3 & 2 & 1 & 0 & 0 \\
\hline X14 & 5 & 3 & 3 & 2 & 0 & 0 \\
\hline X15 & 12 & 5 & 3 & 1 & 0 & 0 \\
\hline X16 & 9 & 6 & 2 & 1 & 0 & 0 \\
\hline X17 & 8 & 7 & 6 & 3 & 1 & 0 \\
\hline X18 & 10 & 6 & 2 & 1 & 0 & 0 \\
\hline X19 & 11 & 6 & 3 & 2 & 0 & 0 \\
\hline SV & 163 & 117 & 60 & 26 & 11 & 5 \\
\hline
\end{tabular}


Pokazatelji u T 3 upućuju na zaključak da veći broj učenika, njih 340 ili $89 \%$, izvanredno, vrlo dobro i dobro obavljaju operacije sabiranja i oduzimanja brojeva u krugu broja 20. Samo pet učenika, ili $1 \%$, nije osposobljeno za računske operacije sabiranja i oduzimanja u krugu broja 20. Za ove učenike nastava će biti prilagođena prema njihovim mogućnostima i sposobnostima i vjerujemo da će uz pojačan pedagoški rad i oni do kraja nastave steći elementarna matematička znanja.

Kroz realizaciju programskih sadržaja nastave matematike nastavnici razvijaju kod učenika preciznost i tačnost, navikavaju ih na istrajnost, upornost i dosljednost, osposobljavaju djecu za saradničke odnose, na spremnost da prihvate pomoć i budu spremni pomoći drugima i niz drugih karakternih dimenzija ličnosti značajnih za uspješan rad $\mathrm{i}$ pripremu za život. ${ }^{9}$

\section{Moja okolina}

Nastavni predmet Moja okolina pruža izvanredne mogućnosti za osposobljavanje učenika za zapažanje promjena na živoj i neživoj prirodi, izoštravanje opažanja, razvoj kognitivnih sposobnosti i konativnih osobina ličnosti sa širokim spektrom aktivnosti u kojima se učenici afirmiraju i bogate svoja znanja i govorne sposobnosti. Od velikog broja zapažanja, našu smo pažnju usmjerili na sagledavanje ostvarenih rezultata kroz dva segmenta: interesa učenika za sadržaje iz predmeta Moja okolina i izražene spremnosti za čitanje sadržaja Moje okoline.

9 Ramić, O, Sposobnosti $i$ osobine ličnosti invalida rata u funkciji edukacije $i$ zapošljavanja, Grafičar, Bihać, 2011. Navedena knjiga primjenjiva je i u odgojnoobrazovnim ustanovama, posebno kada se radi o djeci s teškoćama u razvoju i njihovog uključivanja u redovna odjeljenja. 


\section{T 4: Moja okolina}

\begin{tabular}{|c|c|c|c|c|c|c|c|c|}
\hline$\frac{\stackrel{0}{\vec{D}}}{\frac{\overrightarrow{0}}{\overrightarrow{0}}}$ & 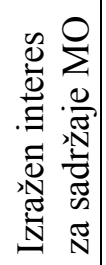 & 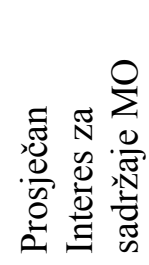 & 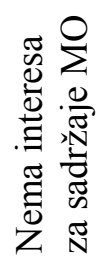 & is & 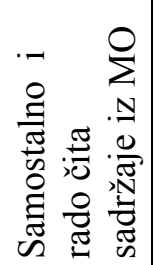 & 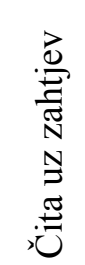 & 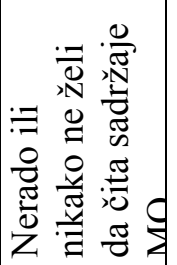 & is \\
\hline $\mathrm{X}$ & 7 & 9 & 4 & 20 & 9 & 7 & 4 & 20 \\
\hline $\mathrm{X} 1$ & 10 & 2 & 1 & 13 & 10 & 2 & 1 & 13 \\
\hline $\mathrm{X} 2$ & 13 & 7 & 1 & 21 & 12 & 8 & 1 & 21 \\
\hline X3 & 14 & 7 & 1 & 22 & 16 & 6 & 0 & 22 \\
\hline $\mathrm{X} 4$ & 6 & 4 & 3 & 13 & 6 & 4 & 3 & 13 \\
\hline $\mathrm{X} 5$ & 17 & 10 & 0 & 27 & 14 & 11 & 2 & 27 \\
\hline X5-a & 14 & 2 & 2 & 18 & 15 & 3 & 0 & 18 \\
\hline X6 & 17 & 4 & 4 & 25 & 18 & 3 & 4 & 25 \\
\hline $\mathrm{X7}$ & 6 & 0 & 0 & 6 & 3 & 3 & 0 & 6 \\
\hline $\mathrm{X} 8$ & 9 & 3 & 0 & 12 & 8 & 3 & 1 & 12 \\
\hline X9 & 10 & 9 & 4 & 23 & 15 & 8 & 0 & 23 \\
\hline $\mathrm{X} 10$ & 4 & 5 & 0 & 9 & 6 & 3 & 0 & 9 \\
\hline $\mathrm{X} 11$ & 11 & 7 & 2 & 20 & 12 & 8 & 0 & 20 \\
\hline $\mathrm{X} 12$ & 14 & 5 & 0 & 19 & 15 & 3 & 1 & 19 \\
\hline $\mathrm{X} 13$ & 12 & 4 & 0 & 16 & 13 & 2 & 1 & 16 \\
\hline $\mathrm{X} 14$ & 11 & 2 & 0 & 13 & 7 & 6 & 0 & 13 \\
\hline X15 & 15 & 6 & 0 & 21 & 15 & 4 & 2 & 21 \\
\hline X16 & 12 & 6 & 0 & 18 & 14 & 3 & 1 & 18 \\
\hline $\mathrm{X} 17$ & 12 & 10 & 3 & 25 & 15 & 9 & 1 & 25 \\
\hline $\mathrm{X} 18$ & 10 & 7 & 2 & 19 & 15 & 4 & 0 & 19 \\
\hline X19 & 10 & 8 & 4 & 22 & 10 & 11 & 1 & 22 \\
\hline Svega & 234 & 117 & 31 & $\begin{array}{c}38 \\
2\end{array}$ & 248 & 111 & 23 & $\begin{array}{c}38 \\
2\end{array}$ \\
\hline
\end{tabular}

Podaci do kojih smo došli daju nam za osnovu da tvrdimo da su učenici zainteresirani za sadržaje iz nastavnog predmeta Moja okolina. To se može smatrati i razumljivim, jer, rijetke su osobe koje ne pokazuju interes prema biljnom i životinjskom svijetu, prema promjenama u prirodi i društvu, prema ljepotama prirode, prema društvenim normama ponašanja. Zato i nije iznenađujuće da 351 učenik, ili njih 91,8 \%, pokazuje izražen ili prosječno izražen interes prema ovim sadržajima. Još 
je bolja situacija kad se posmatraju želje učenika da samostalno i rado čitaju različite sadržaje iz predmeta Moja okolina ili, eventualno, da čitaju uz zahtjev. Tako je 359, ili 93,9 \%, ispitivanih u kategoriji ovih visokih vrijednosti. Ipak, može se primijetiti i da 23 učenika, ili $6 \%$, nerado ili nikako ne pokazuju interes za čitanjem ovih sadržaja, iako je ovo, rekli bismo, teško prihvatljivo. Jednim dijelom to može biti posljedica slabijeg interesa općenito za čitanje. Organizacija nastave u prirodi i osmišljeno aktiviranje i ovih učenika sigurno može promijeniti stanje u pozitivnom smislu.

Sadržaji Moje okoline pružaju velike mogućnosti za razvijanje govornih sposobnosti djece, sposobnosti zapažanja, uočavanja i otkrivanja sličnosti i razlika, razvijanja ljubavi prema prirodi i ljepotama prirode, razvijanje senzornih, psihomotornih i kognitivnih sposobnosti, kao i konativnih osobina i mnogobrojnih karakternih svojstava ličnosti. Stoga im treba posvetiti adekvatnu pažnju i iskoristiti sve prednosti za cjelokupni razvoj ličnosti učenika.

\section{Odgojna područja: Muzička kultura, Likovna kultura, Tjelesni i zdravstveni odgoj}

Sadržaji odgojnih područja pružaju široke mogućnosti za zadovoljavanje interesa učenika, za razvijanje estetskih vrijednosti, njegovanje pravilnog odnosa prema zdravlju i vlastitom tijelu, razvijanje i njegovanje navika kulturnog ponašanja, razvijanje smisla za lijepo. Kroz sadržaje odgojnih područja moguće je razvijati perceptivne sposobnosti, ali i druge spoznajne procese koji čine suštinu razvoja ličnosti. Predmeti Likovna, Muzička kultura, Tjelesni i zdravstveni odgoj na najbolji način doprinose razvoju mnogobrojnih karakternih crta ličnosti među kojima tačnost, upornost, dosljednost, istrajnost, iskrenost, poštenje i altruizam zauzimaju zapaženo mjesto. ${ }^{10}$

\footnotetext{
${ }^{10}$ Ramić, O, Utjecaj karaktera učenika na školski uspjeh i ponašanje, Pedagoški fakultet, Bihać, 2011, str. 49-61.
} 
T 5: Rezultati učenika iz odgojnih područja: Muzička kultura, Likovna kultura, Tjelesni i zdravstveni odgoj

\begin{tabular}{|c|c|c|c|c|c|c|c|c|c|c|c|c|c|c|}
\hline \multirow[b]{2}{*}{$\frac{\stackrel{0}{\overrightarrow{0}}}{\frac{\sqrt[0]{0}}{0}}$} & \multicolumn{3}{|c|}{$\begin{array}{c}\text { Muzička } \\
\text { kultura }\end{array}$} & & \multicolumn{5}{|c|}{ Likovna kultura } & \multicolumn{4}{|c|}{ TOZ } & \\
\hline & 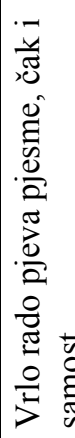 & 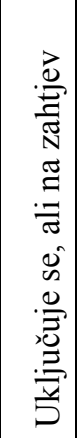 & 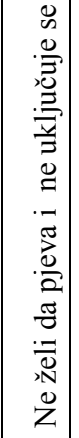 & 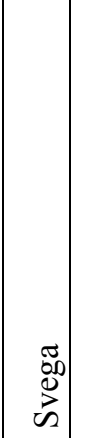 & 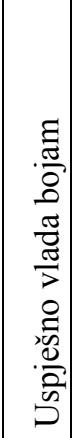 & 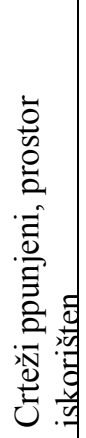 & 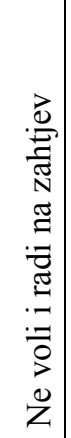 & 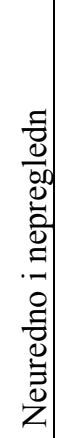 & $\begin{array}{l}50 \\
\infty \\
\infty \\
0\end{array}$ & 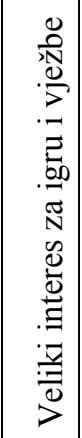 & 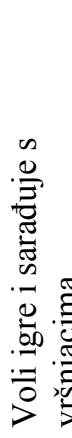 & 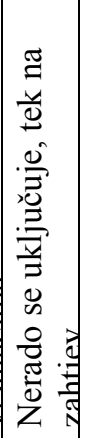 & 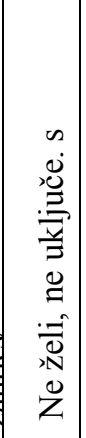 & 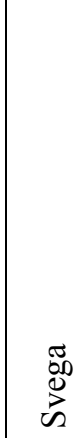 \\
\hline $\mathrm{X}$ & 10 & 9 & 1 & 20 & 9 & 8 & 2 & 1 & 20 & 8 & 11 & 0 & 1 & 20 \\
\hline $\mathrm{X} 1$ & 10 & 1 & 2 & \begin{tabular}{|l|l}
13 & 1
\end{tabular} & 12 & 1 & 0 & 0 & 13 & 13 & 0 & 0 & 0 & 13 \\
\hline $\mathrm{X} 2$ & 11 & 8 & 2 & \begin{tabular}{|l|l}
21 & 1 \\
\end{tabular} & 15 & 4 & 1 & 1 & 21 & 18 & 3 & 0 & 0 & 21 \\
\hline $\mathrm{X} 3$ & 13 & 7 & 2 & \begin{tabular}{|l|l}
22 & 1 \\
\end{tabular} & 14 & 4 & 2 & 2 & 22 & 19 & 3 & 0 & 0 & 22 \\
\hline $\mathrm{X} 4$ & 7 & 4 & 2 & 13 & 8 & 3 & 1 & 0 & 13 & 12 & 1 & 0 & 0 & 13 \\
\hline $\mathrm{X} 5$ & 25 & 2 & 0 & \begin{tabular}{l|l}
27 & 2 \\
\end{tabular} & 26 & 1 & 0 & 0 & 27 & 27 & 0 & 0 & 0 & 27 \\
\hline $\mathrm{X} 5-\mathrm{a}$ & 14 & 4 & 0 & 18 & 16 & 2 & 0 & 0 & 18 & 16 & 2 & 0 & 0 & 18 \\
\hline $\mathrm{X} 6$ & 23 & 2 & 0 & \begin{tabular}{|l|l}
25 & 1 \\
\end{tabular} & 15 & 8 & 2 & 0 & 25 & 22 & 3 & \begin{tabular}{|l|}
0 \\
\end{tabular} & 0 & 25 \\
\hline $\mathrm{X} 7$ & 6 & 0 & 0 & 6 & 6 & 0 & 0 & 0 & 6 & 6 & 0 & 0 & 0 & 6 \\
\hline $\mathrm{X} 8$ & 10 & 2 & 0 & 12 & 8 & 2 & 1 & 1 & 12 & 9 & 3 & 0 & 0 & 12 \\
\hline $\mathrm{X9}$ & 15 & 8 & 0 & 23 & 14 & 9 & 0 & 0 & 23 & 18 & 5 & 0 & 0 & 23 \\
\hline $\mathrm{X} 10$ & 6 & 3 & 0 & 9 & 7 & 2 & 0 & 0 & 9 & 8 & 1 & 0 & 0 & 9 \\
\hline $\mathrm{X} 11$ & 16 & 4 & 0 & \begin{tabular}{|l|l}
20 & 1 \\
\end{tabular} & 13 & 7 & 0 & 0 & 20 & 14 & 6 & 0 & 0 & 20 \\
\hline $\mathrm{X} 12$ & 10 & 9 & 0 & 1911 & 12 & 7 & 0 & 0 & 19 & 13 & 6 & 0 & 0 & 19 \\
\hline $\mathrm{X} 13$ & 12 & 4 & 0 & \begin{tabular}{|l|l|l|}
16 & 1 \\
\end{tabular} & 12 & 4 & 0 & 0 & 16 & 14 & 2 & 0 & 0 & 16 \\
\hline $\mathrm{X} 14$ & 7 & 4 & 2 & 13 & 8 & 5 & 0 & 0 & 13 & 13 & 0 & 0 & 0 & 13 \\
\hline $\mathrm{X} 15$ & 17 & 4 & 0 & \begin{tabular}{|l|l}
21 & 1 \\
\end{tabular} & 18 & 3 & 0 & 0 & 21 & 20 & 1 & 0 & 0 & 21 \\
\hline $\mathrm{X} 16$ & 18 & 0 & 0 & 18 & 18 & 0 & 0 & 0 & 18 & 18 & 0 & 0 & 0 & 18 \\
\hline $\mathrm{X} 17$ & 15 & 10 & 0 & \begin{tabular}{|l|l|}
25 & 1 \\
\end{tabular} & 18 & 6 & 1 & 0 & 25 & 22 & 3 & 0 & 0 & 25 \\
\hline $\mathrm{X} 18$ & 17 & 2 & 0 & 19 & 18 & 1 & 0 & 0 & 19 & 19 & 0 & 0 & 0 & 19 \\
\hline X19 & 20 & 2 & 0 & 22 & 19 & 2 & 1 & 0 & 22 & 21 & 1 & 0 & 0 & 22 \\
\hline Svega & 282 & 89 & 11 & \begin{tabular}{|l|l|}
382 & 2 \\
\end{tabular} & 286 & 80 & & 5 & 382 & 330 & 51 & 0 & 1 & 382 \\
\hline
\end{tabular}

S obzirom na veliki značaj i ulogu odgojnih područja u formiranju i razvoju ličnosti, treba im dati odgovarajuće mjesto i ulogu u odgojnoobrazovnom radu. Rezultati naših skromnih istraživanja pokazuju da 
najveći broj učenika, njih 371 ili $97 \%$, se vrlo rado, ili na zahtjev, uključuje u pjevanje pjesama. Kada je riječ o predmetu Likovna kultura, situacija je također veoma pozitivna. Uspješno korištenje boja, crtanje i slikanje uz popunjavanje prostora veoma je uspješno za 366 učenika, ili 95, 8 \%. Neznatan je broj učenika koji izvršavaju obaveze tek na zahtjev. Za Tjelesni i zdravstveni odgoj možemo konstatirati da svi praćeni učenici pokazuju veliki interes, da vole različite vrste igara i da vrlo uspješno sarađuju s vršnjacima. Dakle, ova odgojna područja, osim što opuštaju djecu, značajno doprinose razvoju međuljudskih odnosa, podstiču altruizam, omogućuju skladnost u razvoju, njegovanju lijepih oblika ponašanja, razvijaju društvenost. Posebno značajan doprinos je u razvijanju zajedničkog rada, odgovornog odnosa prema grupi, ekipi, razvoju samopouzdanja, izgrađivanju pravilnog pogleda prema vlastitom razvoju. Ovo potvrđuje primjer opažanja studentice $M$. H. koja, pored ostalog, navodi:

Lično sam prisustvovala času Tjelesnog odgoja i jako se iznenadila. Dječak koji je na časovima Matematike i Bosanskoga jezika bio jako miran, tih, povučen, nije znao da čita najbolje i kojeg je učiteljica ukorila, na času Tjelesnog odgoja se transformirao u drugog učenika. U učionici mi ga je nekako bilo žao, ali na času Tjelesnog odgoja bio je 'glavni'. Sva djeca su mu dodavala loptu $i$ najviše su dozivala njegovo ime. Jako puno se smijao $i$ zabavljao, pričao sa ostalim učenicima. U razgovoru s učiteljicom saznala sam da on živi sa nanom i ocem, bez majke, i da slabo uči jer niko kod kuće ne utječe na njega i ne pomaže mu. Nakon ovog časa, na ovog učenika sam gledala kao na budućeg sportaša, jako popularnog. ${ }^{11}$

Poseban značaj odgojnih područja je u razvijanju psihomotornih sposobnosti učenika, kao pretpostavke za uspješno bavljenje različitim vidovima slobodnih aktivnosti. Razvoj perceptivnih sposobnosti, pažnje i drugih kognitivnih funkcija, razvoj smisla za lijepo, osjećanje ljepote boja i ljubavi prema prirodi, briga o izgledu vlastitog tijela i gracioznosti u pokretima i kretanju, pravilnog odnosa prema ishrani i načinu života,

11 Psihofizička sposobnost djece drugog razreda devetogodišnje osnovne škole da prate nastavu, seminarski rad studentice Medine Hasić, Bihać, 2012. 
samo su neke od komponenata koje se uspješno razvijaju kroz realizaciju programskih sadržaja odgojnih područja.

\section{Socijalna osjetljivost i emocionalna zrelost}

Prema mišljenju nastavnika, postoji velika razlika među djecom u pogledu socijalne i emocionalne zrelosti. Razlike se kreću u intervalu od veoma socijalno i emocionalno zrele djece, do onih kojima treba i više mjeseci provedenih u školi dok ne dostignu potreban nivo adaptacije i odgovarajući stepen socijalne osjetljivosti i emocionalne stabilnosti. Nastavnici vide rješenje $u$ organiziranju predškolskog odgoja i obrazovanja, posebno u malim, ruralnim sredinama.

Prema mišljenju jednog broja nastavnika, socijalni razvoj kod djece ovog uzrasta je na zadovoljavajućem nivou. Djeca su opuštena i lahko se uključuju u rad i aktivnosti. Pojava privrženosti kao značajnog obilježja dječijeg razvoja, usmjerena je na nastavnika koji je zamjena za majku. Emocionalna stabilnost djece ovog razvojnog perioda varira. Dok su jedni emocionalno stabilni, prilagodljivi, raspoloženi i radno aktivni, drugi su skloni brzim promjenama raspoloženja, čestim burnim reakcijama praćenim i plačem. Nastavnici ističu da je potrebno mnogo raditi na razvijanju prijateljstva, drugarstva, tolerancije, međusobnog razumijevanja, saradnje i pružanja pomoći jednih drugima. Socijalna zrelost i osjetljivost, kao i emocionalna zrelost prisutnije su kod djece koja su bila uključena u predškolski odgoj. Nastavnici ističu potrebu većeg prisustva socijalnog radnika i defektologa, jer smatraju da bi njihove intervencije olakšale ukupni rad u odjeljenju.

U nekim slučajevima, na socijalno i emocionalno stanje i radnu atmosferu u odjeljenju, značajno utječe prisutnost djeteta $s$ teškoćama u razvoju. Njima se mora posvetiti posebna pažnja, prilagoditi rad i ispunjavati njihove zahtjeve, što sve često ide na štetu drugih učenika. U razvoju socijalne osjetljivosti i emocionalne zrelosti značajnu ulogu imaju i roditelji. Njihovo obrazovanje, zainteresiranost i spremnost da pomognu djetetu u njegovom razvoju imaju veliku, ponekad i presudnu ulogu. 
Ne treba izgubiti iz vida činjenicu da uspjeh učenika u učenju značajno ovisi i od toga kakvu dijete ima sliku o sebi, kakvo je njegovo samopouzdanje, kako gleda na svoj uspjeh i postignuća. Zato je veoma važno djecu uključiti u različite oblike aktivnosti u skladu s njihovim mogućnostima i željama jer će to doprinijeti jačanju njihovog samopouzdanja i izgrađivanja pozitivne slike o sebi. Ključnu ulogu u ovom ima nastavnik i njegova procjena šta dijete može i kakve zahtjeve treba imati prema njemu. Dobar i stručan nastavnik će uvijek početi sa zadacima za koje sigurno zna da ih učenici mogu uspješno rješavati i tako ih motivirati za nove napore i veća postignuća. Dakle, nastavnici vode računa o lokusu kontrole kod svojih učenika. Utvrđuje mjesto gdje njegovi učenici određuju (lociraju) odgovornost za svoje uspjehe ili neuspjehe: je li odgovornost u njima, u njihovom angažmanu, trudu i zalaganju - pa govorimo o unutrašnjem lokusu kontrole (ULK). Učenici sa naglašenijim unutrašnjim lokusom kontrole su stabilni, samoinicijativni, sigurni u sebe, istrajni, sa čvrstim samopouzdanjem. Ako svoja postignuća i uspjehe objašnjavaju utjecajem nekih vanjskih faktora i drugih osoba, onda govorimo o vanjskom lokusu kontrole (VLK). Ovi učenici pokazuju nesigurnost, sumnjičavi su, imaju nedostatak inicijative, svoje neuspjehe nalaze u drugim osobama, imaju nisko samopouzdanje. Srećom, rijetki su ekstremni slučajevi pa se kod većine učenika nalaze obilježja i jednog i drugog lokusa kontrole $s$ dominacijom jednog od njih. ${ }^{12}$

Za uspjeh učenika u školskom učenju te za ostvarivanje postignuća, presudnu ulogu ima motiviranost za učenje. S obzirom da je definiranje motivacije veoma kompleksno, poslužit ćemo se jednostavnom definicijom prema kojoj je motivacija sve ono što nas iznutra potiče na neku aktivnost, tj. na postizanje nekog cilja, i što održava tu aktivnost. ${ }^{13}$

\footnotetext{
12 Stojaković, P, Pedagoška psihologija I., Filozofski fakultet, Banja Luka, 2002, str. 321-342.

${ }^{13}$ Petz, B, Uvod u psihologiju, Naklada Slap, Jastrebarsko, 2003.
} 
Nivo mentalne aktivnosti postiže se putem motivacije. Zato Branko Rakić Ističe: Motivacija je sine qua non učenja. ${ }^{14}$

Motivacija se najčešće i definiše kao nešto što pokreće, usmjerava, održava i završava određeno ponašanje. Ona uključuje unutrašnja stanja ličnosti (radoznalost, težnja ka razvoju potencijala i samoaktualizacija), unutrašnja ili intrinzična motivacija, pri kojoj nalazimo zadovoljstvo u samoj aktivnosti, ali i spoljašnje faktore motivisanja (nagrade, kazne, socijalni pritisci), tad govorimo o vanjskoj ili ekstrinzičnoj motivaciji. U školskom učenju važna je i unutrašnja i vanjska motivacija i treba im poklanjati jednaku pažnju. ${ }^{15}$

Motivacija za postignućem smatra se jednom od najvažnijih vrsta motivacije. Ona predstavlja opću tendenciju stremljenja ka uspjehu i tendenciju biranja aktivnosti usmjerenih ka cilju i uspjehu. Prema Atkinsonu (1964.), ljudi mogu pokušati postići cilj na dva načina: stremeći ka uspjehu ili izbjegavajući neuspjeh. Neke osobe su više motivirane da izbjegnu neuspjeh, nego da postignu uspjeh, dok su druge više motivirane za postizanje uspjeha, a manje pridaju značaj izbjegavanju neuspjeha. Odgajatelji su osobe koje trebaju znati prepoznati kod svojih učenika ove težnje, kako bi ih na pravi način usmjeravali i poticali na aktivnost. ${ }^{16}$

\section{Opisno ocjenjivanje, da ili ne?}

Uh... To mi je bolna tačka. Hitno trebamo vratiti stari način ocjenjivanja. Ne znam cija je ideja da se uvede opisno ocjenjivanje. Djeca sa opisnim ocjenjivanjem ne doživljavaju ništa, ne znaju da pročitaju svoju opisnu

\footnotetext{
14 Rakić, B, Motivacija i školsko učenje, Zavod za izdavanje udžbenika, Nastavna biblioteka, Sarajevo, 1997, str. 10.

15 Stojaković, P, Pedagoška psihologija I., Filozofski fakultet, Banja Luka, 2002, str. 321-342..

16 Vizek-Vidović,V., Vlahović-Štetić, V., Rijavec, M., Miljković, D, Psihologija obrazovanja. IEP Vern. Zagreb, 2003.
} 
ocjenu i ne mogu da razumiju svoj opis u knjižici, ali i mnogi roditelji to ne $z n a j u$, nažalost, ističe nastavnica sa solidnim pedagoškim iskustvom. ${ }^{17}$

Uvođenjem devetogodišnjeg osnovnog odgoja i obrazovanja došlo je i do promjena u sistemu ocjenjivanja učeničkih znanja. Za uzrast učenika prve trijade propisi nalažu da se vrši opisno ocjenjivanje. Ovaj vid ocjenjivanja podrazumijeva sistematsko praćenje napredovanja svakog učenika $\mathrm{i}$ detaljno vrednovanje kvaliteta učeničkih postignuća. U određenim vremenskim intervalima, uz korištenje različitih kvalitativnih elemenata, nastavnici iskazuju uspjeh i napredovanje učenika. Ovo ocjenjivanje zahtijeva kontinuitet u opservacijama $\mathrm{i}$ evidentiranju napredovanja učenika. Opisno ocjenjivanje omogućava učenicima i njihovim roditeljima da imaju povratne informacije o napredovanju djece $i$ njihovom zalaganju. Pored niza prednosti, opisno ocjenjivanje ima i svoje nedostatke. Prije svega, smatra se da nema onu motivacionu snagu koju ima brojčano ocjenjivanje. Veliki broj roditelja, također, lakše, smatra se, vide rezultate učenja i nivo postignuća svoga djeteta u odnosu na drugu djecu. Nastavnici moraju biti dobro osposobljeni za graduiranje učeničkih postignuća. Zato se mišljenja nastavnika o opisnom ocjenjivanju kreću od onih koji ovaj vid praćenja napredovanja, vrednovanja i ocjenjivanja prihvataju kao izvanredno rješenje, do onih koji priželjkuju da se što prije napusti i vrati brojčani sistem ocjenjivanja na svim razvojnim uzrastima djece. Ipak, opisno, kao i brojčano ocjenjivanje, mora biti zasnovano na jasnim i čvrstim kriterijima - da je kontinuirano, podsticajno, da uvažava sposobnosti i mogućnosti učenika, da uvažava specifičnosti i ni u kom slučaju da ne zanemari potrebu uvažavanja individualnih razlika među djecom, kao i djecu s teškoćama u razvoju i niz drugih karakteristika.

Uvažavajući sve prednosti i nedostatke opisnog ocjenjivanja, mišljenja smo da bi bilo korisno primijeniti blagi prijelaz s opisnog na brojčano ocjenjivanje. Ovo bi podrazumijevalo da se u III razredu devetogodišnje osnovne škole primjenjuje opisno ocjenjivanje za odgojna područja, a da se ostali nastavni predmeti ocjenjuju brojčano. Tako bi se, mislimo, u

Mišljenje jednog od anketiranih nastavnika. 
četvrtom razredu učenici znatno lakšs prilagodili potpunom prelasku na brojčano ocjenjivanje.

\section{Analiza rezultata ankete}

U toku istraživanja nastavnicima je ponuđen anketni list kako bi mogli iznijeti svoja opažanja i mišljenja o nekim pitanjima koja se odnose na devetogodišnju osnovnu školu. Radno iskustvo nastavnika koji su uključeni u istraživanje kreće se od 3 do 20 godina, s dominacijom nastavnika sa 15 i 16 godina nastavnog rada.

Svi anketirani nastavnici su nedvojbeno izjavili da su zadovoljni izborom poziva i da s ljubavlju izvršavaju obaveze prosvjetnog radnika.

Preovladava mišljenje nastavnika da polazak u školu djece sa šest godina starosti nije smetnja uspješnoj realizaciji programskih zahtjeva u devetogodišnjoj osnovnoj školi. Smatraju da bi programski sadržaji pojedinih nastavnih predmeta trebali biti jasniji, precizniji i obimom prilagođeniji ovoj djeci.

Iako su mišljenja različita, ipak preovladava mišljenje nastavnika da su udžbenici neprilagođeni uzrastu učenika, da su neprecizni i sa mnogo grešaka, da bi ih trebali raditi timovi stručnjaka, da budu tako urađeni da mogu trajati duže, bar četiri godine, da za svaki nastavni predmet bude jedan udžbenik te da budu usklađeni sa zahtjevima nastavnog programa.

Od pedagoške službe očekuju više stručne savjetodavne pomoći, jer polugodišnji i godišnji seminari, kao i posjete $s$ ciljem praćenja izvršavanja administrativnih obaveza, ne mogu zadovoljiti potrebe nastavnika kada je u pitanju stručna pomoć.

Jedinstveni su u ocjeni da je opremljenost škole nastavnim sredstvima i pomagalima kao i stručnom literaturom, jedan od ključnih faktora uspješnog rada nastavnika i uspješne realizacije programskih sadržaja. Posebno izražena potreba za nastavnim sredstvima i pomagalima je u ruralnim sredinama, ali i prigradske i gradske škole oskudijevaju $s$ najosnovnijim nastavnim sredstvima, a o savremenoj tehnici suvišno je i govoriti. 


\section{Zaključci i prijedlozi mjera}

1. Naši skromni rezultati upućuju na zaključak da je reforma sistema odgoja i obrazovanja nužan proces i da je neophodno da zahvati sve nivoe, od predškolskog do visokog odgoja i obrazovanja. S obzirom na ostvarene rezultate $\mathrm{u}$ realizaciji programskih sadržaja II razreda dvetogodišnje osnovne škole, smatramo da su naša hipoteza i podhipoteze $\mathrm{u}$ cijelosti potvrđene $\mathrm{i}$ da ne treba dovoditi $\mathrm{u}$ pitanje opravdanost uvođenja devetogodišnje osnovne škole;

2. Međutim, smatramo da se reforma sistema treba provoditi istovremeno na svim nivoima odgojno-obrazovnog sistema, a ne samo da počinje i završava na nivou osnovne škole. Ovaj proces mora imati svoj kontinuitet i provoditi se na ostalim nivoima odgoja i obrazovanja. Upis učenika iz devetogodišnje osnovne škole u srednju školu ne bi trebao biti isti za svu djecu, jer se onda ne vidi potpuna svrha provođenja reforme sistema odgoja i obrazovanja. Opravdano se nameće pitanje jesu li djeca sa završenom devetogodišnjom osnovnom školom izgubila godinu svog bezbrižnog djetinjstva i da li je reforma ostvarila svoj cilj;

3. Jedna od osnovnih pretpostavki reforme sistema odgoja i obrazovanja jeste efikasna osnovna i srednja škola i drugi nivoi obrazovnog sistema. U vezi s tim, nužno je bilo izvršiti izmjene u NPP-a koje bi se temeljile na pokazateljima koji su rezultat temeljitih istraživanja efekata svakog odgojno-obrazovnog nivoa. Nastavna praksa ovu potrebu potvrđuje. Longitudinalno istraživanje vrijednosti NPP-a sigurno bi dalo dovoljno elemenata za temeljite izmjene i dopune nastavnih planova i programa, čime bi se u značajnoj mjeri otklonile uočene slabosti i odgojnoobrazovni nivoi učinili funkcionalnijim i efikasnijim;

4. U toku provođenja našeg skromnog istraživanja, došli smo do spoznaja o kvalitetu udžbenika koji se koriste u drugom razredu osnovne škole. Mišljenja nastavnika, koja smo već iznosili, ukazuju na veliku potrebu usklađivanja udžbenika sa zahtjevima nastavnih planova i programa. Vlada velika šarolikost, nejasnost i nepreciznost, što odgajateljima otežava rad. Smatramo da bi udžbenike trebali raditi timovi stručnjaka (pedagozi, psiholozi, defektolozi, sociolozi i nastavnici iz prakse). Izradu novih 
udžbenika trebalo bi zasnivati na vrijednostima postojećih, s tim da bi morali biti usklađeni sa razvojnim karakteristikama djece za koju su namijenjeni i sa zahtjevima NPP-a;

5. Reforma sistema odgoja i obrazovanja pretpostavlja, pored ostalog, praćenje i razvojnih karakteristika djece različitih starosnih uzrasta. Fizički razvoj, psihički razvoj (razvoj kognitivnih sposobnosti), socijalni razvoj i emocionalno sazrijevanje (kao konativne dimenzije ličnosti), razvoj govornih sposobnosti, podsticanje razvoja interesa, sklonosti, želja te usklađivanje mogućnosti sa zahtjevima škole - sve su to elementi koji $\mathrm{u}$ procesu reforme moraju biti temeljito praćeni i na čijim rezultatima treba zasnivati opravdanost provođenja reformskih zahvata;

6. Opisno ocjenjivanje, da ili ne? Prema sadašnjim važećim propisima, opisno ocjenjivanje na području USK se provodi na nivou prve trijade osnovne škole. Praćeno je prednostima i nedostacima. Smatramo da bi bilo opravdano primijeniti blagi prelazak $s$ opisnog na brojčano ocjenjivanje, koji bi se ogledao u tome da se u III razredu osnovne škole primijeni opisno ocjenjivanje za odgojna područja, a za ostale nastavne predmete da se vrši brojčano ocjenjivanje. Naše mišljenje je da bi ovaj blagi prijelaz na potpuno brojčano ocjenjivanje u IV razredu dao pozitivne efekte;

7. Vannastavni i vanškolski rad pruža izvanredne mogućnosti za podsticanje razvoja djece u svim segmentima i na svim nivoima. I površne opservacije upućuju na zaključak da se ovom segmentu odgoja i obrazovanja učenika ne poklanja adekvatna pažnja. Upravo su ovo područja u kojima se na najbolji način podstiče razvoj perceptivnih, psihomotornih i spoznajnih sposobnosti, kao i razvoj karakternih crta ličnosti. Zato je neophodno stvarati pretpostavke za uspješnu realizaciju sadržaja vannastavnih i vanškolskih aktivnosti, podjednako u gradskoj, prigradskoj i seoskoj sredini. 


\section{Literatura}

1. Hwang, P., Nillson, B.(2000.) Razvojna psihologija. Sarajevo: Filozofski fakultet

2. Petz, B. (2003.) Uvod u psihologiju. Jastrebarsko: Naklada Slap

3. Rakić, B. (1970.) Motivacija i školsko učenje. Sarajevo: Zavod za izdavanje udžbenika

4. Ramić, O. (2006.) Sposobnosti i osobine ličnosti invalida rata u funkciji edukacije i zapošljavanja Bihać: „Grafičar“

5. Ramić, O. (2007.) Specifičnosti rada s djecom prvog razreda osnovne škole. U: S. Topoljak (ur.) Zbornik radova 1 (str. 263-281), Bihać: Islamski pedagoški fakultet

6. Ramić, O. (2011.) Utjecaj karaktera učenika na školski uspjeh i ponašanje. Bihać: Pedagoški fakultet Univerziteta u Bihaću

7. Rathus, S. A. (2000.) Temelji psihologije. Jastrebarsko: Naklada Slap

8. Stojaković, P. (2002.) Pedagoška psihologija I. Banja Luka: Filozofski fakultet

9. Vizek-Vidović., Vlahović-Štetić., Rijavec, M.,Miljković, D. (2003.) Psihologija obrazovanja. Zagreb: IEP Vern

10. Vasta, R.,Haith, M.M., Miller, S. A. (1998.) Dječja psihologija. Jastrebarsko: Naklada Slap

\section{Internet izvori}

1. www.sobih.ba/siteoo/images/stories/galerie/zakonska_akta/okvirni npp.pdf 


\section{Osman Ramić, PhD}

\section{THE EDUCATIONAL ACHIEVEMENT OF THE SECOND GRADE PUPILS IN THE NINE-YEAR PRIMARY EDUCATION}

Abstract

The first generation of pupils enrolled in the nine-year primary schools have finished their education during the school 2012/2013 year. Because of this, the need for evaluation of the achieved results, learning outcomes and goals is set even higher. Havng this in mind, and with a special assignment related to the monitoring of developmental features of six year-old pupils in order to enhance students' knowledge in the area of developmental psychology, we have conducted a research of which we bring our humble observations.

Actuality of monitoring of progress, evaluation and assessment of pupils' achievement does not stop and it will never stop. The need for constant monitoring of the educational achievements was even more highlited at the time of the first aplication of the nine-year basic educational system and descriptive assessments in the first triad of primary school. Information regarding the outcomes of learning are needed, not only for pupils, but also parents, guardians, teachers and all other entities that are in any way involved in the education of children.

In order to monitor the mental and physical development of children and the compliance between development and requirements of the nine-year primary education, students of the Pedagogical Faculty of the University of Bihac have conducted a research on the educational achievements of pupils in the second grade of nine-year primary school.

Keywords: reform, learning strategies, learning outcomes, achievement, motivation, locus of control, descriptive assessment, social sensitivity, emotional stability, teacher and student competencies 


\section{الأستاذ الدكتور عثمان راميتش ^1^}

حول إنجازات الصف الثاني التعليمية والتربوية من المدرسة الابتدائية ذات السنوات التسع لئ والتربون

\section{الخلاصة}

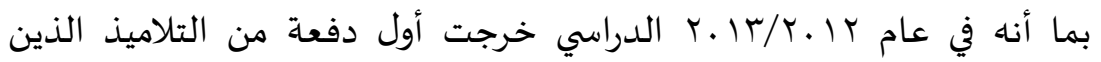

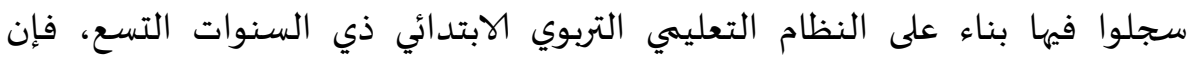

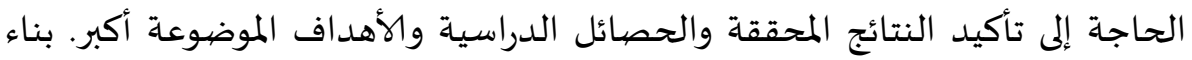

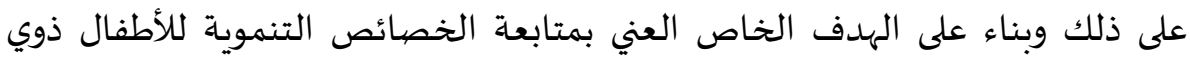

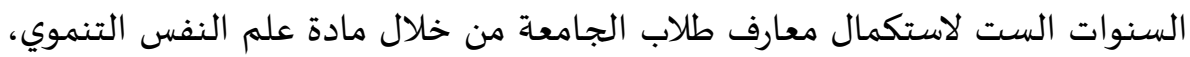

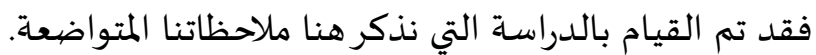

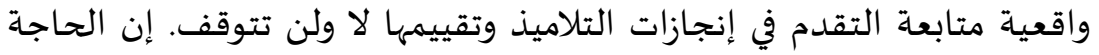

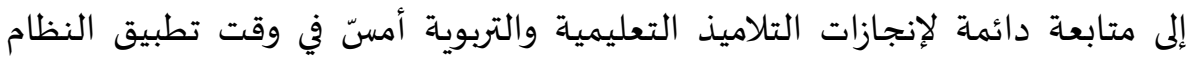

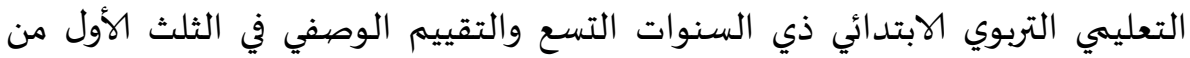

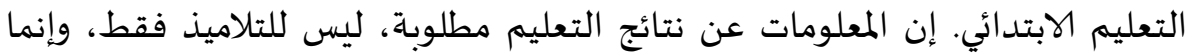

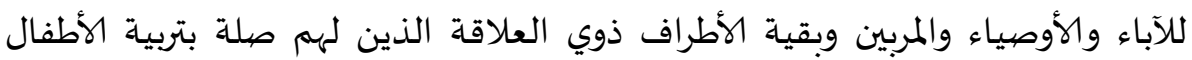
وتعليمهم.

بهدف متابعة تنمية الأطفال النفسية والجسمية والتوافق بين التنمية ومتطلبات

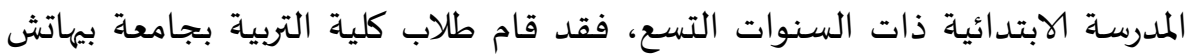

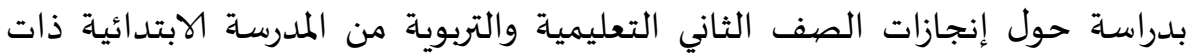
السنوات التسع.

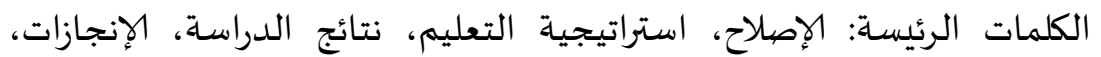

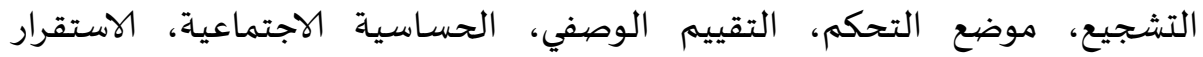
العاطفي، كفاءات المدرسين والتلاميذ. 